\title{
The intangible legacy of the Indonesian Bajo
}

\author{
CHANDRA NURAINI
}

\begin{abstract}
The Sama-Bajau, or Bajo diaspora, extends from the southern Philippines and Sabah (Malaysian Borneo) to the eastern part of Indonesia. The Indonesian Bajo, now scattered along the coasts of Sulawesi (Celebes) and East Kalimantan, the Eastern Lesser Sunda Islands and Maluku, were once mostly nomadic fishermen of the sea or ocean freight carriers. Today, the Bajo are almost all fishermen and settled. Their former and present ways of life made them favour intangible forms of culture: it is impossible to transport bulky artefacts when moving frequently by boat, or when living in stilt houses, very close to the sea or on a reef. It is therefore an intangible legacy that is the essence of the Bajo's culture. Sandro healers have a vast range of expertise that allows them to protect and heal people when they suffer from natural or supernatural diseases. On the other hand, music and especially oral literature are very rich. In addition to song and the pantun poetry contests, the most prestigious genre is the $i k o-i k o$, long epic songs that the Bajo consider to be historical rather than fictional narratives. The Bajo's intangible heritage is fragile, since it is based on oral transmission. In this article, I give a description of this heritage, dividing it into two areas: the knowledge that allows them to "protect and heal" on the one hand, and to "distract and relax", on the other.
\end{abstract}

KEYWORDS

Sama-Bajau; Bajo; Eastern Indonesia; nomadism; intangible legacy; epics; fishermen communities; iko-iko; preservation.

\section{INTRODUCTION}

The Sama-Bajau people are dispersed over a vast area, from the southern Philippines (Sulu Archipelago), to Malaysia (Sabah, northern Borneo), to Indonesia (eastern part of the Indonesian archipelago). The Sama-Bajau of Indonesia, who call themselves either Bajo (an adopted exonym) or Sama, live in remote coastal villages that are separated from each other, built either on the coast or on the reef itself, with ingenious houses on stilts. Formerly, many of the Bajo people were sea nomads who lived all year round on their small

CHANDRA NURAINI, born in 1965, is an associate professor of Indonesian and Civilization of Indonesia at the University of La Rochelle (France), where she teaches Indonesian language and culture since 1996. In 2008 she holds a PhD degree in Ethnolinguistics from the same university. Her research focuses on the language and oral literature of the Bajo people in Indonesia. Chandra Nuraini may be contacted at: cnuraini@univ-lr.fr.

(C) 2016 Faculty of Humanities, University of Indonesia

CHANDRA NURAINI | DOI: 10.17510/wacana.v17i1.427 
boats, and subsisted through fishing or, more rarely, through marine transport activities. Now they are almost all settled, under the combined pressures of economic change and the Indonesian administration. They continue, at least in Indonesia, to generate all of their income from the sea: they are almost all fishermen, and often indebted to wealthy local ship-owners.

Whether the Indonesian Bajo are former nomads, or have always lived in coastal villages (which do not exclude travels and migrations), they have retained a fascinating intangible heritage. As communities sometimes move, living in a dangerous environment and precarious housing, material wealth is necessarily very succinct. They can by no means accumulate artefacts or build stone buildings and the only permanent sites on land are cemeteries. The visual arts are minimized, and most of the Bajo genius is expressed through oral literature and knowledge of the natural and supernatural worlds. The Bajo culture is preserved, enhanced, and primarily verbally transmitted. ${ }^{1}$

The Bajo culture does not make any distinctions between sacred and profane, utilitarian and aesthetic. In this article, I will deal with the intangible heritage linked to healing know-how, of body and soul. Of course there are plenty of other manifestations of Bajo culture that deserve to be examined in detail, both intangible (music and oral literature) and tangible (shipbuilding, architecture, and carving). The material and spiritual worlds are permeable to each other. Empirical medical knowledge and ritual processes are inseparable when sandro (healers) protect and treat the body and the soul. The principal mode of artistic expression is oral literature, including the $i k o-i k o$ epics, often including cathartic roles that soothe tensions and offer dreams. I will describe the two essential aspects of the intangible Bajo heritage, therapy and artistic expression, and divide this description into two sections: the knowledge that allows "protection and healing" on the one hand, and "entertainment and relaxation", on the other.

My data were acquired during fieldwork stays, between 2002 and 2013, mainly in Kangean (East Java, Sumenep regency at the eastern tip of Madura), then East Flores and Sulawesi.

1 The Bajo empirical knowledge on boating, fishing, and boat manufacturing is very rich. Therefore, we will not discuss it in this article. The Bajo sailors are able to navigate without any instruments, by identifying the stars and currents, over very large distances. 


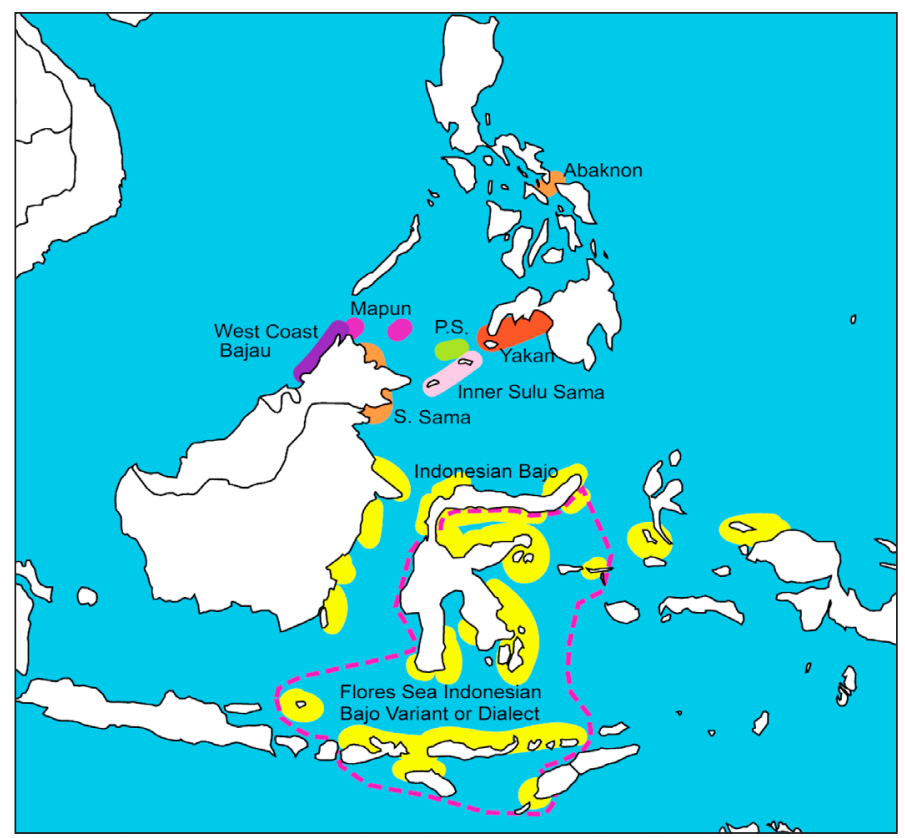

Map 1. Sama-Bajau languages map. P. S.: Pangutaran Sama. S. Sama: Southern Sama. The Inner Sulu Sama cluster comprises three languages: Balangingi Sama, Central Sama, and Southern Sama. The area of the Flores Sea Indonesian Bajo variant or dialect is represented inside a dotted line. Map by P. Grangé. Data compiled from www.ethnologue.com and Jun (2005: 377-396).

\section{PROTECTION AND HEALING}

In Indonesia, the Bajo's living conditions are generally precarious. Regarded almost everywhere as newcomers, ${ }^{2}$ they rarely have any property title, and may be expelled as soon as a conflict regarding the use of coastal lands appears, $^{3}$ or if the landowner who allowed them to settle on the shore sells or bequeaths his property. It is only when a Bajo village has been settled for several generations ${ }^{4}$ that the property becomes incontestable; the legal status of houses built on stilts above the water (reef or mangrove) remains unclear. ${ }^{5}$

2 In reality, the Bajo are sometimes the "first comers" on the coast, arriving before the interior populations become interested in the coast. For example, in the Kendari Bay (Southeast Sulawesi) and probably in many small islands such as Kangean (East Java), the Bajo were the first to establish themselves in the eighteenth century,.

3 In Wuring, near Maumere (north coast of Flores), the Bajo conquered a vast sea peak, thanks to consistent backfilling to build their homes. This peak is now coveted by the city of Maumere to install a commercial port, on the pretext that the Bajo have no property title - and for good reason, since this peak is artificial. Only the number and determination of the Bajo of Wuring can derail this abusive project.

4 See Liebner (1998) "Four oral versions of a story about the origin of the Bajo people of southern Selayar."

$5 \quad$ Indonesian law states that any marine area is state property (the same is true in France). The solution would be to provide long-term concessions (as for example, for pearl oyster farming) to those who build houses on stilts. The Indonesian Bajo Association has 
The Bajo villages are usually settled in places that nobody wanted: no access to water (especially on small islands), or on land unsuitable for agriculture. Almost all Bajo are fishermen, and are subject to the vagaries of the monsoon winds, the scarcity of fish, and often the debt cycle and monopsony ${ }^{6}$ of their owner-lender-buyer. Under these harsh conditions, with periods of several days to several weeks where navigation is impossible, women and children must contribute, for example, by collecting shellfish in the mangrove.

The Bajo are often frowned upon by inland populations, although mixed marriages are common. ${ }^{7}$ Trading markets, where women sell or exchange fish with agricultural or manufactured products, are held daily. Although the majority of Bajo speak the regional language well (the contrary is not true), cohabitation is exerted at best with indifference. Among other criticisms frequently made to Bajo, one is particularly whispered: beware of their supposed black magic rituals that are terribly powerful. I heard the same remarks, perfectly reciprocal, among the Bajo regarding the indigenous people (especially in Flores), a clear sign of distrust.

Most Bajo do not feel safe, economically, ${ }^{8}$ physically, and spiritually. It is important for them to protect themselves, not only from diseases, but also from people's malice. In fact, there is no difference in nature between a disease and torment caused by the malice of others or the hostility of invisible beings. In addition, poverty, isolation and difficult access to health services are incentives for the conservation and application of an empirical and traditional knowledge, to protect and heal each other. The holders of such knowledge are the sandro.

claimed this possibility, but the Ministry of Fisheries and Oceans (Departemen Kelautan dan Perikanan) has neither considered nor proposed any bill regarding this claim.

6 Monopsony is a situation where the buyer is unique, facing several producers. This is the opposite of monopoly.

7 The number of marriages between Bajo and the ethnic majority is quite varied by region. For example, unlike people in Flores who are predominantly Catholic, the Bajo are Muslims, which constitutes a serious blockage for intermarriage. When the ethnic majority is Muslim, the obstacles are rather economic or customary: the Bajo do not own land or capital, other than their production tools. The dowry required for the benefit of the bride's family leads to the fact that the majority of marriages involve Bajo women with "Bagai" men (non-Bajo).

8 The Bajo are often indebted to the "bosses" who buy their fish and/or lenders of their production tools. The Bajo who manage to make savings retain these savings in the form of gold jewellery, easy to resell, if necessary. Some Bajo (especially in Southeast Sulawesi), if they make enough profit from their catch, try to buy nearby fields, with apparently two objectives in mind: securing capital (possibly transferable for a dowry or a big expense) and to have a burial place. The vegetables that are grown in these fields, often entrusted to a local farmer, rather than reflecting a shift towards agriculture, denote a waiting situation; the Bajo themselves admit they have no talent or interest in agriculture. 


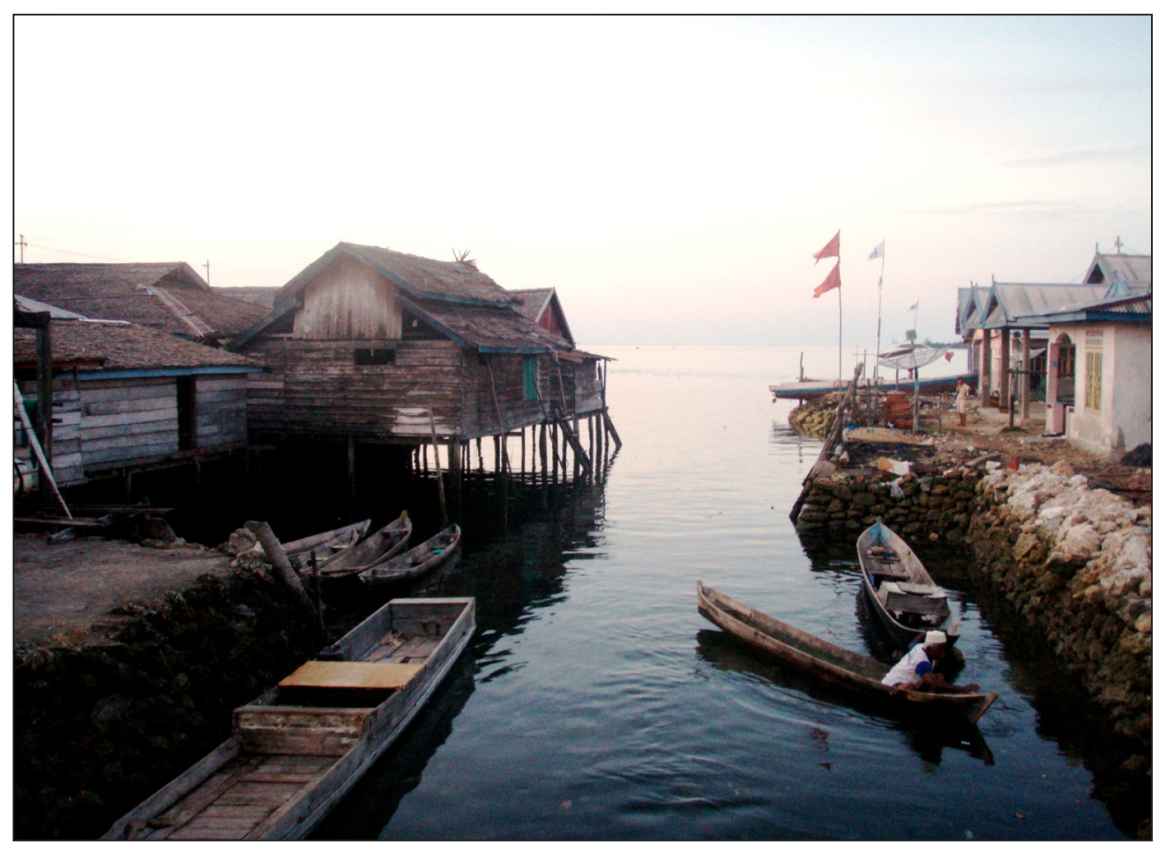

Figure 1. A Bajo village in Southeast Sulawesi (photograph by the author).

\section{The sandro healers}

I have no knowledge of Bajo manuscripts concerning the body, diseases, and treatments, as for example, in Java. The only physical media to protect and care for others consist of tiny objects, talismans, and offerings deposited at sea or on land. All these artefacts obviously mean nothing by themselves, without the mediation of insiders, the sandro healers.

The sandro, both women and men, take their knowledge from one or several older sandro, often direct ascendants. However, a sandro told me that some of the remedies he applies were indicated to him in dreams. The sandro fall into two categories according to their competence. Based on my investigations, mainly in the Kangean archipelago (East Java), Maumere (Flores), and Southeast Sulawesi, I will successively describe the sandro anak (children sandro) and the sandro panambar (sandro healer), simply called sandro.

The sandro anak, ${ }^{9}$ exclusively women, take care of the child before birth, around the seventh month of pregnancy. Through massages, they correct the position of the baby, if necessary, whose sex they can guess. They ensure the mother has a healthy and balanced diet, making her eat fruits, such as papayas or sweet potatoes, which will increase breast milk production. They tell pregnant women what precautions to take: not to go out at sunset, not

9 At least three sandro anak are active in the small island of Sapeken in the Kangean archipelago, Eastern Java. Sapeken Island is populated by 11,000 inhabitants, mostly Bajo. On this island, the bidan also perform obstetrics and act as midwives, trained according to Western medicine. 
to expose oneself to the wind, and to sleep a lot. These guidelines do not distinguish between physiological and spiritual precautions. The sandro anak willingly work with bidan (midwives) during childbirth. After birth, the sandro anak prepare an ointment with ashes of certain plants, which will be coated around the newborn's navel, to hasten healing. The placenta is covered with salt and seafood pulp, and is then buried (we will see why later). Then every day, for forty days, the newborn is massaged and the sandro anak remind the young mother that she should not have intimate relations with her husband.

The sandro healers, or simply sandro, are supposed to cure all kinds of diseases of the body and soul. The Bajo also call them pandrite (in Kangean) or duata. ${ }^{10}$ The sandro do not make medicinal drinks (they only drink pure water), but they make offerings and recite mantras for preventive or curative reasons. Many examples of mantras, adapted to various situations (travel, construction, ceremonies, therapies, etcetera) were collected and analysed by Syarifuddin (2008) and Uniawati (2007). All Bajo people that I know have been involved, at least once in their life, with a sandro. The absence of health clinics in the village, or the lack of qualified personnel if there is a health clinic, obviously maintains the social utility of the sandro. It is only in the case of a serious accident or obvious failure of the sandro that the patient is taken to the hospital in the nearest town, sometimes within a day's sailing. The sandro's role is not only to cure diseases, but also to protect and fight against any possession by an evil spirit. These possession crises, accompanied by trances, prostrations, and/or incomprehensible words, are not rare in Bajo communities. The sandro cure them by making the possessed person drink pure water while reciting mantras. To exorcise their patients, they can also bring the evil spirit to their bodies, thus entering into a trance themselves.

The sandro may seek protection from the spirits before any important undertaking, especially before a Bajo undertakes a sea or land travel. Thus, he asks the Mbo dilaut 'sea ancestor' for protection for leaving on a long journey. A similar request is made for any person (Bajo or bagai, that is non-Bajo) who comes to live temporarily or permanently in a Bajo community. This request is accompanied by a ritual of making an offering on the surface of the sea, from a canoe. If the offering drifts out to sea before sinking, it means that the request is accepted. However, if the offering drifts towards the coast, it means that the offering is denied and the traveller or newcomer must abandon his/ her project.

Unambiguously, the sandro consider themselves good Muslims. However, the pre-Islamic religion remains, implicitly and in conjunction with the Muslim religion, and is characterized by rituals intended to reconcile the deified ancestors: the Mbo (ma) dilau(t) (sea ancestors) and the Mbo (ma) didarat

10 The sandro are also called duata by communities around the Flores Sea (South and South-East Sulawesi and Flores). The duata term probably comes from dewata, of Sanskrit origin referring to the deities. Thus, by metonymy, those who interact and negotiate with the gods themselves are designated by that name. 
(land ancestors). Rituals accompany birth, illness, and death, ${ }^{11}$ consisting primarily of mantras recited by the sandro and offerings deposited on land or, more often, on the surface of the water. The sandro's dialogue with spirits manifests itself in the chanting of mantras and the sandro's lips moving, as if holding a conversation that humans around them cannot hear. The sandro may voluntarily enter into a trance, their voice changes, and they seem to be unaware of the people around them. At the end of the trance, the sandro come back to themselves, exhausted, and need time to recover their strength.

Obviously, these rituals are the remains of a pre-Islamic religion but never considered as inconsistent with the practice of Islam. The Indonesian Bajo embraced Islam only since the eighteenth century in the wake of their allies and protectors, the Bugis, and were sometimes mocked by other ethnic groups because they appeared to be "little civilized", ${ }^{12}$ lacking a monotheistic religion. This has probably become the cause of the Bajo's inferiority complex, and in some communities, the classic tendency among new converts is to adopt an ostensibly pious behaviour. ${ }^{13}$ Another classic way to resolve contradictions between the traditional religion and monotheism is syncretism. Thus, in some Southeast Sulawesi Bajo communities, the figure of the Mbo madilaut 'sea ancestor', literally 'ancestor at sea', is merged with the figure of the Prophet Muhammad's companion. Our informants insisted that he is not a God (which would be a very serious sacrilege), but a companion of the Prophet who gained immortality and is now living in the sea. The Mbo madilaut is thus presented as a unique being, while according to other communities there are several Mbo madilaut or Mbo madidarat, who continue to act as protective ancestors of their direct descendants. In all cases, the Mbo madilaut provides a protective role, and can be invoked not only by the sandro, but by any Bajo. At sea, the Bajo fishermen seek him through mantras in order to appease the waves, to raise the wind, or to attract fish.

\section{Hazards and diseases}

The Bajo fear the jealousy and malice of others in their community or from "land" residents. One may wonder who could be envious of a family of fishermen living in poverty and responsible for a significant number of children. But in the case of recurring problems - health, domestic incidents, or bad fish catches - intentional malice is suspected. Threats can come from deceased persons, namely ancestors who believe their descendants are ungrateful or disrespectful.

11 See Nimmo (1972) and Bottignolo (1995).

12 This condescending opinion seems to persist vis-à-vis the Sama-Bajau or the Sama Dilaut, in the southern Philippines, Mindanao or the Sulu Archipelago.

13 In the Kangean Archipelago, the pesantren or religious boarding schools are numerous and reflect a very rigorous practice of Islam. The Kangean archipelago trains more religion professors than can be used in public or private schools. The veil is almost always worn by women when they are away from home. It is not correct to wander at sunset, during Maghrib prayer time. At Sapeken, about 10 years ago, public flogging of supposed adulterous couples was still common. The proximity of Madura may explain this severity of manners. 
Any exceptional event exhibiting the dynamism, ambition, or success of a family is a source of potential danger. This may be the launch of a new boat, the building of a new home, but also family ceremonies, such as marriage or circumcision. The Bajo are more individualistic and the family is hardly extensive, relatively resembling small family structures in Europe. But during ceremonies, the circle of extended family and friends come to help in the preparations and participate in the festivities. It is therefore necessary to avoid any adverse action performed using black magic, and sandro can be called on to protect the family during any special event.

One will note in Bajo villages the absence of any common rituals aimed at preventing natural disasters (epidemics, storms, and etcetera). This is not just an effect of the Bajo individualism. These collective rites have almost completely disappeared, for fear of violating Islamic law. Propitiatory rites are practiced discreetly, with a relatively small number of people, for example, in connection with the construction of a home or the completion of a ship. Cultural activities that accompanied the lives of some villages have been removed or limited, out of fear of violating the religious dogma. For example, yacht races around the Isle of Sapeken were removed in the 1980s, on the pretext that they began with an offering made at sea. The traditional dance has also disappeared from the island. Some villages are trying to resurrect these collective activities, by giving them an explicitly Muslim appearance (for instance, by conducting Quran recitation contests or announcing calls to prayer), sometimes accompanied by activities that are unambiguously secular (games, sports, traditional songs, or parades with heritage objects). The organizers make sure these events do not express any statement of protest or sensitive political content. ${ }^{14}$

Frequent pathologies in Bajo have not been studied specifically. The diet of fish and rice is frugal and healthy, but unfortunately, children regularly consume junk food (sweets, dried noodles chewed out of the bag). The children's habit of jajan (eating snacks) is not uncommon in Indonesia, but among the Bajo, if we compare with, for instance, that of children in West Java villagers, the amount has increased significantly. The children can ask for small change several times a day from their parents, who can be stripped of the meagre amount of money that they own. It is amazing to see how fathers, rugged fishermen, give in to their children's whims, who may cry and stomp their feet to get a 5.000 Rupiah banknote, immediately spent at the nearby kiosk. Assuming they are still hungry for dinner, their mothers will have prepared their meal with taste enhancers such as monosodium glutamate (Vetsin) without moderation; these chemicals are now considered as indispensable as salt, which may lead to new diseases. In addition, men

14 A "Bajo Festival" was held in November 2013 in the Wakatobi archipelago (South East Sulawesi). The Bupati (prefect) and President of the Association of Indonesian Bajo stressed that it was not a manifestation of sukuisme (clannishness); rather, it was meant as an opportunity to better understand and appreciate the cultural resource of each ethnic group. The event consisted of traditional dances, canoe competitions, and other sports. [Http://www.antarasultra.com/ berita/269031/bupati-wakatobi-buka-festival-internasional-suku-bajo, accessed on 24-11-2013.] 
smoke a lot. When adults pass away, usually nobody knows the cause of their deaths, which sometimes happen dramatically fast, such as ones triggered by "nausea" or "stomach aches". On the other hand, infectious diseases appear to be rather rare.

Diseases of the body and soul, as well as recurring accidents, are interpreted holistically. The Bajo believe that prevention is better than cure. I will show some examples of precautionary measures performed by the Bajo to protect themselves and their families.

\section{Protection rituals}

During the Idul Fitri (Eid ul-Fitr) celebration or the Islamic new year, most families ask a sandro to come to their homes for a quick propitiatory rite that will protect the family: he burns a little incense, reciting in a murmur Al Quran surahs and mantras, for instance, mantras that consist of many repeated sentences or phrases from the Quran, at least in the introduction, so that nobody sees any contradiction between the practice of Islam and the remains of pre-Islamic rites. In the days following Idul Fitri, the sandro go from house to house for a propitiatory rite of five to ten minutes per family.

Until recently, the Bajo did not give names to newborns. This tradition has somewhat disappeared in urban areas where administrative bodies are present, as parents must register the birth. The family usually gives a nickname to the child, without intent to ridicule, according to its physical characteristics, for example "Bignose", "Voracious", "Little Boy", "Benjamin”, or strange and grotesque nicknames, such as "Swarthy" or "Testicle". Names of everyday objects can also be used as nicknames: "Pole", "Paddle", "Keel", "Spoon", and etcetera. No surname is transmitted from parents to children. I know many adults, especially men, who are finally never given a name, and that everyone continues to call him, for instance "Kid," even though he himself may have become a grandfather. Keeping a secret name, or changing it in case of illness, is not exclusive to the Bajo traditions; in the Javanese community, it is customary to change the name of a child who often gets sick. The Bajo develop an extreme distrust of the proper name, choosing a very ordinary, even vulgar meaning. I believe this is a precaution for the protection of the child: with an ordinary name such as "Rudder" or "Net", how can a curse via black magic reach its destination? However, Bajo families who claim to have descended from the lolloh (aristocracy), and generally have a slightly higher cultural and economic status than the rest of the population, give names to their children immediately, generally using Arab-Muslim names with surnames. It is possible that having a respected surname is itself a shield against any malicious occult ritual.

Newborns are protected from malicious poppok (po'po' or popoka) by a simple device: mantras whispered by the sandro and a clove of garlic skewered on a bamboo stick, planted in the ground near the threshold of the house. The poppok are evil beings that roam the night in search of dung and human 
excrement, ${ }^{15}$ including placentas after childbirth (which is why the placentas are covered with salt and bitter fruit before being buried). The poppok are particularly fond of blood, and the newborns are for them the most sought after delicacies. This belief is firmly rooted in all Bajo communities I met, and its evocation causes discomfort and sneers full of innuendo. Indeed, the poppok are humans, with a sort of shameful disease, which transforms them during certain nights into evil and despicable beings. They are more or less associated or confused with owls (burung hantu); or in Flores Bajo communities, with venomous centipedes (kaki seribu). Variants of this myth are widespread in the Austronesian world and beyond. ${ }^{16}$ Everywhere, it is suggested that "some people" in the village are poppok, and these suspicious people are always bagai (non-Bajo). Their description varies somewhat from one community to another, about their ability to fly, their hanging entrails, their disgusting tongue/trump, or the way to extort a treasure: a poppok caught in action, in order to escape shame and condemnation, would have no choice but to give the gold and jewels to the one who surprised them.

A means to protect themselves from physical attacks or magic is to wear a talisman. The talisman is prepared by a sandro, who, through mantras, instils a protective spirit in the talisman. It is mostly young children who wear it, but its use is not excluded in some adults; the talisman remains carefully hidden under the clothing. In children less than one year old, the talisman is mainly intended to ward off diseases. For adults, the goal is to guard them against black magic and acquire physical or psychological strength. It is difficult to investigate such a personal matter, but oral literature can provide insight into the use of talismans during combat. Several iko-iko epics that I have collected mention baressu mapan (talisman, literally 'strong stone'). These talismans are intended to protect the fighter in combat, including duels, as in the following excerpt:

Mallin ran leaping to hit the chest of Captain Talili and also dodged him to the right. Talili fell flat on his stomach to the left, and he stood up against the mat of the arena. "You're acting proud, miserable Bajo, do you not know this is a baressu mapun?" said Captain Talili. Mallin saw a kind of salak ${ }^{17}$ core on Captain Talili [on

15 This belief is particularly strong in Sapeken Island, where it is said that at night, the poppok feast with faeces stranded on the beach. Indeed, in this tiny, overcrowded island, the lack of toilets in most houses force the inhabitants to defecate on or beside the beach, which is permanently stained, and it is a popular belief that ubiquitous and disgusting poppok are prone to promiscuity and lack of hygiene.

16 There is a striking resemblance with the myth of strigae in Greco-Roman antiquity. It was believed that they turned into owls and found their way into houses to suck the blood of newborns. "There are ravenous birds, with huge heads, staring eyes, sharp beaks for robbery: their feathers are white and they have hooked claws. They say they tear the bowels of those who still feed only on milk and they love to get drunk with their blood. They are called strigae because of their sinister and terrifying cry at night." Ovid, The Fasti, Book 6. The resemblance between the ancient Greek myth of and the Bajo poppok (and its Austronesian variants) remains inexplicable.

${ }_{17}$ The core of the salak measures half a centimetre in diameter; it is black, smooth and shiny. In this scene, it is assumed that the fighters are shirtless and that the talisman is attached 
his chest]. Mallin pointed his weapon behind him, because he launched his attack from the bottom to the top until it reached [Talili]'s chest. (Talili lines 754-759)

Mallin, the $i k o-i k o$ hero, himself under the protection of a powerful magical ancestor, kills his opponent by spearing upwards, so as to bypass the talisman.

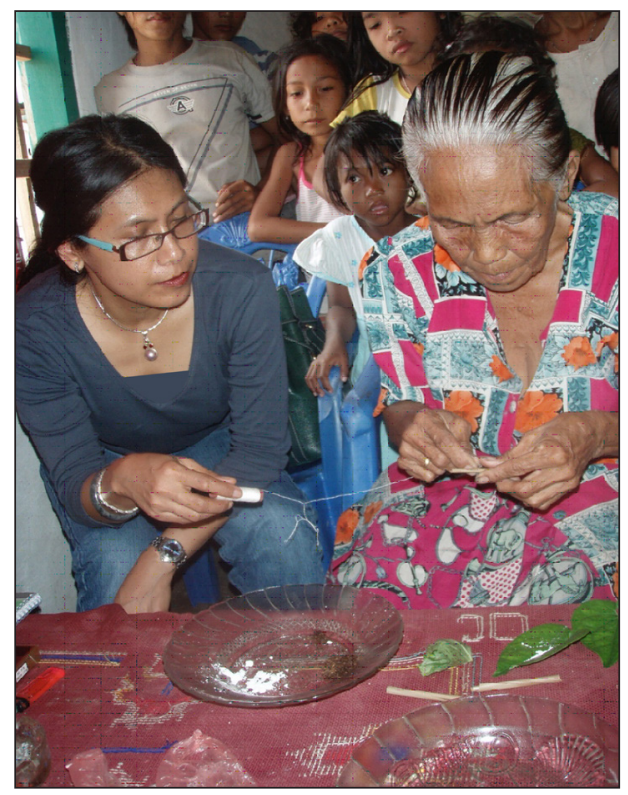

Figure 2. A sandro woman (right) prepares an offering, assisted by the author (left) (photograph by P. Grangé).

\section{Diagnosis and treatment}

The sandro sometimes diagnoses disorders of supernatural origin. The symptoms are variable: physical weakness, depression and prostration, trances and confused monologue, and shooting pains. The aggressor may be another person (a Bajo or a bagai) via a sandro follower of black magic. ${ }^{18}$ The aggression is even more dangerous if it comes from a direct ancestor who feels the descendants have been ungrateful or disrespectful, or another ancestor who seeks to redress an insult initiated by the direct ancestor of the victim. It is the role of the sandro to explain the origin of the evil; he/she decrypts the diagnosis using his/her knowledge and through dreams or trances. In Southeast Sulawesi, the aggression comes through an animal medium: a turtle,

to a necklace. The rules of the duel (perhaps inspired by the Bugis) are as follows: the public gathers in a round arena. The opponents, each armed with a kris, challenge and inveigh against each other, recalling all the causes and issues of the conflict. In the middle stands a mast, against which leans one of the opponents. His enemy launches an attack, and the one who has his back to the mast can dodge or parry the blow but cannot counter the attack. The roles alternate until one of the opponents is knocked out.

18 We have never encountered such sandro. According to our informants, it is always "other" sandro, supposedly greedy and cynical, who put their knowledge at the service of hateful people. We cannot say that these evil sandro actually exist. 
octopus, or sea crocodile. The animal is considered to be an invisible spirit rather than a living being, but it happens that the victim sees one of these animals before falling seriously ill. In the Bajo community of Muna, there are many stories mentioning canoes overturned and pulled to the seabed by a monstrous octopus with tentacles. ${ }^{19}$

Unexpectedly, the most harmful of these three spirit-animals is the sea turtle. If the sandro detects that the patient was attacked by a turtle, the patient's life is endangered. The octopus (except in reported cases of capsizing) and crocodiles are, in their supernatural forms, less dangerous but can cause death if no therapy is initiated. The link between these three spirit-animals and the Mbo madilaut is not clear; according to some informants, the animals are mediums of the Mbo madilaut; for others, they are avatars of the Mbo madilaut; and still others believe that there is no link, these beings merely sharing the same marine environment.

The sandro puts all his/her attention and energy into serving these serious cases. He/she is putting his/her reputation at risk, and is assisted if necessary by other sandro. The patient remains in bed in his/her house or the sandro's house. The treatment procedure includes mantras and offerings to be deposited on the surface of the sea. ${ }^{20}$ During this treatment, which can last for weeks, it is also important that the patient, and only he/she, consumes at least once the flesh of the offending animal. This requirement may seem paradoxical; indeed, the consumption of these animals is (almost everywhere in Indonesia, even in the Austronesian world) taboo, or subject to very strict conditions. ${ }^{21}$ They may be taboo for consumption because they represented, in religious systems now forgotten, totems or mythical ancestors of various clans (for instance, crocodile or swordfish clan ancestor in myths of origins that remain alive in the case of the Indonesian archipelago, in the Lesser Sunda Islands, or in the Eastern Moluccas). The sandro were unable or unwilling to tell me why it is necessary, when one is attacked by a spirit-animal, to consume the flesh of the corresponding species; perhaps it should be seen as a kind of inversion of the taboo, being symmetrically able to heal a patient and to harm a healthy person.

\section{ENTERTAINING AND RELAXING}

It is easily understood that the Bajo's heritage is essentially intangible: what non-utilitarian objects could be taken away on a boat five or six meters long, or

19 Such stories, collected in Southeast Sulawesi (Muna Island) are interspersed with specific details: names of the victims, as well as dates and locations of incidents. So much so that one might wonder if it would not be a posterior interpretation of fishing accidents (sinking, embolism when diving with an air hose). We should also keep in mind that the marine fauna are poorly known in this region, and there could be giant squid in the depths. On the other hand, saltwater crocodiles, although very rare, are extremely dangerous.

20 Bottignolo (1995) describes in detail therapies in Bajo communities (Sama-Dilaut) of the Sulu Archipelago, Philippines.

21 Only certain families or holders of symbolic functions can consume them and only during major events. This is particularly the case of the turtle, often reserved for the leaders (in Melanesia), or consumed exclusively during a ceremony (in Bali). 
be kept in a house on stilts exposed to winds and waves? Rumours are that few manuscripts have been preserved (though I could not verify this), or acquired by museums (often reluctant to share information or provide consultation) but more often, a high-ranking family only remembers possessing manuscripts, accidentally destroyed (for example, by fire or the tsunami of 1992 in Maumere) or lost during a stampede (bloody rebellion in South Sulawesi in 1950 or in Eastern Flores in the 1960s). Some lollo (noble) families in Southeast Sulawesi have retained rare heritage objects: kris, spears, and gongs, remains of a distant time when the Indonesian Bajo roamed the seas as carriers (of spices, sea cucumbers, pearls, and slaves) and rendered service to the Goa-Makassar Sultans, then to the Bone Sultans. The visual arts are being abandoned, yet the Bajo were outstanding sculptors and wood carvers, as evidenced by the last soppet (vertical or convex bow boats) and the ridge beams of old houses and tombstones. Dance is also disappearing, both under pressure from religion (the fear of being considered as "bad Muslims") and from fashion folk dances conveyed by the media throughout Indonesia, such as joget dangdut.

This is an intangible heritage which is the heart of the Bajo culture, a fragile heritage based on learning from "initiated masters" and memorization. The desire to learn and communicate is essential, otherwise one generation losing interest in the cultural heritage is sufficient to break the chain of transmission of knowledge. This is what is happening in many Bajo communities, and what has happened in those in contact with cities or subsumed by the rapid urbanization of coastlines.

\section{Traditional music}

Traditional Bajo music uses mundane instruments known in the Malay world: the gendang (tambourine) and gambus (viola of Arabic origin). The Bajo do not use the gamelan (percussion copper and bronze ensemble); the ancient gongs kept in the lolloh families once were used on ships, ${ }^{22}$ not part of a gamelan ensemble. An instrument more specific to the Bajo is the pipiu, a reed flute with a palm leaf pavilion. The tinny sound of the pipiu has the distinction of being continuous: the flutist breathes in and out without any break during the performance. Bajo traditional music is strongly challenged by the dangdut, Indonesian pop music, even at weddings.

\section{Oral literature}

The Bajo oral literature includes the following genres: pantun (poems), illigo or kodandio (songs), and the $i k o-i k o$ (epic narratives).

The pantun is a classic poetic genre in the Malay world. ${ }^{23}$ In its classic form, it is a very short poem (quatrain) whose first couplet is a metaphor relating a scene from everyday life, or depicting various juxtaposed natural elements,

22 In $i k o-i k o$ epics, it is reported that the gong on board of a ship is struck to announce the arrival in a bay, or during undocking.

23 The pantun is the only literary genre of the Malay world to have had some echo in France in the late nineteenth century, in particular with Hugo and Baudelaire. 
while the second elucidates the first couplet, in the manner of a proverb or a fable with a moral lesson. In the Bajo communities, the pantun are more akin to sharp dialogues, memorized or improvised on canvas. The jousting pantun full of sensual or saucy innuendo formerly animated weddings, with girls and boys discussing poetically, encouraged by the public's laughter and admiration. At a wedding, the newlyweds themselves can give the reply. Here is an example heard at Sapeken (Kangean archipelago) at the end of a wedding, when the young man comes to his in-laws to spend the first night with his wife. He is standing in front of the house at the foot of the ladder while she is inside, and the hilarious public is all around:

- Do you authorize me to dock my boat?

- I beg you to come in front of my house, so that I may see the goods you bring.

- It's only a worthless fish that I can give you.

The illigo (or iligo) songs are sung a cappella or accompanied by instruments (Arabic gambus viola, stringed bamboo, or pipiu flute). They evoke passions and disappointments in love in a romantic and melancholic tone. Kodandio (or kondandio) songs are very long lullabies, telling of outstanding accomplishments. Only older women still know kodandio songs and know how to make children sleep this way.

The $i k o-i k o$ or $i k i k o$ are the most prestigious and most developed genre of Bajo oral literature. They are epics sung a cappella, memorized by one singer, male or female. Iko-iko are sung in the evening, on various occasions (night fishing, boat launch, completion of a house, eve of a wedding, etcetera) and they last from one hour to more than fourteen hours (during two nights). Iko$i k o$ are sung in prose; the rhythmic phrases are grouped into verses and are separated by a long vowel, also sung. The literary devices used also become part of the beauty of the work: metaphors, similes, narrative "patterns", but are also remains of parallel compositions (paraphrases in pairs), typically Austronesian. The $i k o-i k o$ genre is common to all the Sama-Bajau, and has been documented under the name of kata-kata in the Sulu South Philippines (see Revel et al. 2005).

The fear of attacks by pirates is a common thread running through iko$i k o$. Pirates were real enemies for the Bajo when the $i k o-i k o$ storylines were set as they still are today, because pirates repeatedly raided coastal villages or fishing prahus, to capture and sell people as slaves (until approximately 1850 in Eastern Indonesia). Besides, the practice of "lover's abduction" (with the beloved's consent and complicity, a Bajo tradition which has not vanished) is implicitly reflected by the typical episode of a long journey undertaken with the heroine through the forest, on the pretext of escorting her to a well where she will take a curing bath. A beautiful iko-iko gives listeners a catharsis (for example appeasing intra-community tensions or alleviating the fatigue of fisherman who must be on guard all night). This catharsis is manifested by whispered acquiescence or even tears. Beyond the emotion, the edifying 
adventure of the Bajo heroes, seen as real historical figures, restores a sense of pride to the Bajo, reaffirming their identity. It is worthy to note that the $i k o-i k o$ are not entirely tragic. There are some humorous elements that periodically occur, probably in order to alleviate the dramatic tension. There are also erotic allusions that only adult listeners of the $i k o-i k o$ can understand; this is generally the case when the $i k o-i k o$ is offered at the occasion of a wedding party.

The $i k o-i k o$ are anonymous works, which singers declaim word for word, exactly as they have learned them. Only the style of singing and the melody would have a personal touch. In reality, it is likely that in a specific scenario, the singer embroiders a little bit by adding or subtracting adventures and "patterns", small repetitive scenes that emphasize the character of the main characters.

\section{Echoes of Bajo history in the iko-iko}

It is impossible to say when an $i k o-i k o$ was set in its current form; the question itself may be ill posed, if we assume that a text is alive and may have evolved over the centuries. In the $i k o-i k o$ I recorded, the rare references to technical objects are no more recent than the nineteenth century: they involve, for instance, an engraving or a picture, an iron bed, a marble table, or a lipstick from Holland. Certainly, older objects are mentioned, for example, a row of cannons on a ship, whose detonation is followed by a large cloud of white smoke. More interesting is the mention of trade and maritime transport in which the Bajo excelled with their allies and protectors, the Bugis. For example, a bajo sailor, Sameune, buys tree bark in the Moluccas, and sells it 4,500 km further west, in Singapore. ${ }^{24}$

The Bajo consider the $i k o-i k o$ not as fiction but as historical narratives, the only ones they possess, since the origin and stages of their diaspora have fallen into oblivion. Some admit that these stories have been embellished with wonderful elements, while others argue that these fabulous adventures are authentic events. Thus, the Si Hasan iko-iko, sung by Wak Najan in Sapeken (Kangean archipelago) is not considered fiction: a man of about 80 years, Wak Bul, maintains from family tradition that his great-grandfather is none other than Hasan, the eponymous hero of this $i k o-i k o$. If this is correct, the real Hasan would have lived between 1850 and 1870. No historical record makes it possible to take this narrative for granted; Hasan's adventure would in any way have gone unnoticed in the eyes of the Dutch colonial administration, which had little interest in the Bajo, a people without a specific territory.

Place names mentioned in the iko-iko correspond to actual places on the land, but the heroes' villages or original islands are rarely mentioned. In any case, toponymy gives no clue about the author or the date of the composition

24 This role of the ocean for the Bajo has been completely removed, certainly due to the stranglehold of the VOC in Southern Sulawesi in the seventeenth century (Makasar) and eighteenth century (Boné-Bugis). Only the Bugis were able to maintain marine transport activity within the Indonesian archipelago until today. Currently, almost all Bajo are fishermen and poor. 
and recomposition of each epic narrative. Even the mention of Singapore (Singapura in Malay), officially founded in 1819 by Thomas Raffles, does not ensure that the Sameune iko-iko is subsequent to its founding. First, the stages of the hero, including Sameune's journey, have been modified by successive singers while keeping the storyline. Then, the Bajo themselves claim that in the long-term, their sailor ancestors frequently travelled to the natural shelter offered by Singapore for centuries. They named this port Sellah. ${ }^{25}$

A historical phenomenon largely addressed by the $i k o-i k o$ is that of piracy. The Bajo villages were sometimes victims of raids by pirates presumably coming from Seram (Moluccas) and the Southern Philippines (Ilanun); the Bajo having little wealth, it was the men and women themselves that were taken and sold as slaves. On the other hand, the Bajo sometimes became the collateral victims of inter-tribal wars in the Celebes (outside Southern Celebes, where they were under the protection of the Bugis). These tribes, under the generic name of Toraja, ${ }^{26}$ practiced headhunting. In the $i k o-i k o$, the term Toraje therefore refers to both maritime pirates and enemies from the interior. Many $i k o-i k o$ mention a well-controlled by the Toraje; approaching it, let alone bathing in it is extremely risky: invariably, the Toraje, armed to the teeth, would burst out and attack. The terror inspired by these pirates is reflected in the iko-iko: they are particularly cruel, but the hero confronts them alone and slaughters or subjugates them. The Dutch colonial army managed to eradicate piracy in the Indonesian archipelago in the mid-nineteenth century.

We know that sometimes, in the nineteenth century, the Bajo sailors transported slaves captured by other ethnic groups (mainly in Flores) (see Verheijen 1986). One finds an implicit echo in some $i k o-i k o$, where the heroes, after defeating the pirates, bring the pirates' chief to the village as a slave. A magic formula allows the hero to enslave a pirate and make him loyal as a dog to his master. The enslaved pirate is sometimes described as very strong, with "square shoulders, able to shred a chicken with his hands" (Nuraini 2008: 236) and silent, only obeying the hero. This suggests a foreign origin: the prisoner did not speak the Sama-Bajo language; he is culturally uprooted (a basic principle of slavery). His physical strength is impressive, which could be one of the characteristics of people from the Small Islands of the Eastern Sundas (Flores, for example) and Eastern Indonesia, who are generally larger, stronger, and bolder than the Bajo.

\section{The future of the iko-iko genre}

The popularity of cheap audio-visual entertainment devices and the attraction of young people to the external signs of modernity leave no chance to the $i k o-$

25 Bajo informants in various communities in Indonesia have offered me a bold etymology for Singapore, with the Bajo words singga 'calling at a port' and poré 'here', 'to stop here'. This fictional etymology may, however, reinforce the Bajo pride for their glorious past as maritime traders.

26 Today, the Toraja ethnonym means only one ethnic group located in the province of Sulawesi Selatan (Southern Celebes). 
iko genre. In Sabah, a Malaysian province in Northern Borneo, in the North Coast Bajau communities, there are only a few written traces of the $i k o-i k o$ genre (Sather, personal communication). The fifteen $i k o-i k o$ epic singers that I have identified in Indonesia are all old, and no young person wants to make the effort to remember and sing these epics.

Only older women still know kodandio lullabies. Younger generations prefer to fall asleep to the TV, permanently lit in the evening (electricity is distributed from 6 pm to 6 am in large towns). Not surprisingly, the $i k o-i k o$ songs remain more alive in very isolated villages without electricity. The correlation between the arrival of electricity (and television) and the disappearance of oral literature is evident in the Bajo communities and elsewhere. TV now sells them insipid serials and consumerist dreams invented in Jakarta.

I am pessimistic about the future of Bajo oral literature. It is urgent to protect it by, on the one hand, saving it through recordings and written transcriptions, and on the other, actively promoting it to young people to encourage interest in their traditional culture, an initiative that can only come from the Bajo themselves. The Association of Indonesian Bajo does so, within the limits of its material resources. The Bajo, being a minority in all the districts or provinces where they live, ${ }^{27}$ are unlikely to receive public subsidies to support their cultural activities.

\section{CONCLUSION}

The Bajo intangible legacy is fragile because it is based on verbal transmission. In this article, I examined a particular field of this heritage, related to the healing of body and soul. The art of sandro, which protects each person from supernatural attacks and teaches the way to relieve the body and the soul from these attacks still look pretty solid because Western medicine has had little penetration in Bajo society. In the medium-term, traditional knowledge to protect and heal will not disappear. However, the knowledge which can entertain people and make them relax is threatened in the short-run. This oral literary heritage is vanishing at an alarming rate, due to the combined effect of globalization and the geographic dispersion of the Bajo communities. The ubiquity of cheap audio-visual entertainment devices (such as TV, which broadcasts popular music) leaves no chance to the $i k o-i k o$ genre. I have recorded about $30 i k o-i k o$ in Indonesia, then transcribed and translated seven of them. It is out of the question to maintain this heritage for the exclusive use of researchers. With the agreement from the singers, I will provide the recordings and transcripts (with their translation in Indonesian) to the Bajo who wish to use them. In conjunction with other efforts, including the Association of

$27 \quad$ No official census allows us to know how many Bajo live in Indonesia because censuses are done according to the administrative division, such as kabupaten (district/regency) and propinsi (provinces). In addition, the ethnic definition is irrelevant because the Bajo define their identity mainly through their language. The Bajo community is very open; intermarriages with other communities are commonplace. We estimate the number of people identifying themselves as Bajo to be between 300,000 and 400,000 people in Indonesia. However, they have very few elected representatives because of their diaspora. 
Indonesian Bajo, I hope that this work will maintain and enhance a wonderful legacy that future Bajo generations will one day want to rediscover.

\section{REFERENCES}

Bottignolo, Bruno. 1995. Celebrations with the sun; An overview of religious phenomena among the Badjaos. Manila: Ateneo de Manila University Press. Jun, Akamine. 2005. "Sama (Bajau)", in: Adelaar, A. and N. P. Himmelmann (eds), The Austronesian languages of Asia and Madagascar, pp. 377-396. New York: Routledge.

Liebner, Horst. 1998. "Four oral versions of a story about the origin of the Bajo people of southern Selayar", in: Robinson, K. and M. Paeni (eds), Living through histories; Culture, history and social life in South Sulawesi, pp. 19-23. Canberra: Research School of Pacific and Asian Studies, Australian National University.

Nuraini, Chandra. 2008. Langue et production de récits d'une communauté Bajo des îles Kangean. PhD thesis, Université de La Rochelle.

Nimmo, H. Arlo. 1972. The Sea People of Sulu. San Francisco: Handler Publishing Company.

Revel, Nicole et al. 2005. Le Voyage au Ciel d'un Héros Sama/The voyage to heaven of a Sama hero. Silungan Baltapa. Paris: Geuthner.

Syarifuddin. 2008. Mantra nelayan Bajo; Cermin pikiran kolektif orang Bajo di Sumbawa. PhD thesis, Universitas Gadjah Mada.

Uniawati. 2007. "Mantra melaut suku Bajo; Interpretasi semiotik Riffaterre". MA thesis, Universitas Diponegoro.

Verheijen, Jilis A.J. 1986. The Sama/Bajau language in the Lesser Sunda Islands. Canberra: Australian National University. [Pacific Linguistics Series D / Materials in languages of Indonesia 32.] 